\title{
MOLT CYCLE OF THE NATURAL POPULATION OF PALAEMONETES ARGENTINUS (CRUSTACEA, PALAEMONIDAE) FROM LOS PADRES LAGOON (BUENOS AIRES, ARGENTINA)
}

\author{
Mónica M. L. Felix ${ }^{1}$ \\ Ana M. Petriella ${ }^{2}$
}

\begin{abstract}
The molt cycle of the natural population of Palaemonetes argentinus Nobili, 1901 from Los Padres Lagoon, Buenos Aires, Argentina, was studied in relation to age, sex, and environmental factors. A total of 1645 individuals (740 females, 539 males, and 366 juveniles) were collected and analyzed between December 1995 and December 1996. The results indicate that the sex ratio (males:females) remains around 1:1.4 throughout most of the year. The reproductive period extends from September until February (spring and summer), with maximum sexual activity in October and November. Two cohorts originated in the spring and in the summer were differentiated. Ovigerous females arrest their molt cycle during the intermolt period to restart it after oviposition. The duration of the intermolt period does not differ between adults and juveniles. Since the percentage of premolt individuals represents $60 \%$ of the total cycle, it was classified as a diecdysic cycle. Within the studied range of water temperatures, the observed variations in the span of the different stages, indicate that this factor does not alter the molt frequency. Like in the rest of decapods, the intermolt duration of $P$. argentinus is modified by ovarian maturation.
\end{abstract}

KEYWORDS. Palaemonetes, Decapoda, Palaemonidae, molt cycle, ovarian maturation.

\section{INTRODUCTION}

The bodies of crustaceans are limited by rigid exoskeletons that determine a peculiar type of growth. The growth appears as a discontinuous phenomenon that takes place in staggered increments, whose most evident manifestation is the molting process or ecdysis. The increase in weight and size after each molting event obeys to an increase in the volume of the body fluids and the subsequent tissue growth. The neurohormonal regulation of the molt cycle is affected by diverse external and internal factors, being temperature and photoperiod the most relevant ones among the first group, and age, sex, and gonad maturity the most important ones among the second group (HARTNOLL, 1982; LiPCIUS, 1985). The relationship between molting and maturation has been investigated endocrinological and physiological factors (DRACH, 1955; BLISS, 1966; ADIYODI \& ADIYODI,

\footnotetext{
1. Depto Biología, Facultad de Ciencias Exactas y Naturales (FCEN), Universidad Nacional de Mar del Plata (UNMP), Funes 3250, $3^{\circ}$ piso, B7600 Mar del Plata, Argentina. (mfelix@mdp.edu.ar)

2. Depto de Ciencias Marinas, FCEN, UNMP. CONICET.
} 
1970; AdIYOdi, 1985; AiKen 1969, 1980; ChANG, 1993).

Palaemonetes argentinus Nobili, 1901 is widely distributed in South America, extending from southern Brazil to central Argentina (Rodrigues Capítulo \& Freyre, 1989). Several studies have been published on this species concerning larval development (Menu Marque, 1973), growth (Rodriguez Capítulo \& Freyre, 1989), reproductive biology (Goldstein \& Lauría De CidRe, 1974; Schuldt \& Damborenea, 1989), survival and fecundity (Rodriguez CApítulo, 1992), bioecological aspects (DonatTi, 1986), and morphology (Sousa et al., 1997; Sousa \& Petriella, 2000, 2001; Díaz et al., 1998); however the molt cycle of natural populations had never been investigated.

The aim was to study the molt cycle of a natural population of the freshwater prawn P. argentinus from Los Padres Lagoon, Argentina, by analyzing its relationships with age, sex, and environmental factors.

\section{MATERIAL AND METHODS}

Approximately 120 specimens of P. argentinus from Los Padres Lagoon ( $\left.37^{\circ} 57^{\prime} \mathrm{S}, 57^{\circ} 44^{\prime} \mathrm{W}\right)$, Buenos Aires, Argentina, were collected monthly, between December 1995 and December 1996. Samples were taken with hand net in the littoral zone of the lagoon, at depths ranging from 60 to $80 \mathrm{~cm}$, where reed stands of Schoenoplectus californicus (C. A. Mey Soják) dominate. This species has a patchy spatial distribution, its abundance relative to a standard capture effort, was estimated by counting all the individuals randomly caught in the first five net tows. Prawns were fixed in situ with $5 \%$ formaldehyde, and then counted, weighted (to the nearest $0.0001 \mathrm{~g}$ ), and measured in laboratory. Total length (size) was measured under stereoscopic microscope, from the anterior end of the rostrum to the posterior edge of the telson. Individuals measuring less than $15 \mathrm{~mm}$, that did not show secondary sexual characters, were considered as juveniles. Individuals were sexed by examining the first and second pleopods (DonatTI, 1986). Ovigerous females were recognized by the conspicuous presence of eggs. Part of samples of $P$. argentinus are deposited in Laboratorío de Fisiologia de Crustáceos, FCEN.

The molt stage of each individual was determined by microscopic observation of the developmental stage of the exopodite setae of the uropods (Díaz et al., 1998). Following Drach \& TCHERNigOvtZeFF (1967), molt stages were grouped into postmolt (A and B), intermolt (C), and premolt $\left(\mathrm{D}_{0}, \mathrm{D}_{1}\right.$, and $\left.\mathrm{D}_{2}\right)$. The molt cycle categorization herein adopted follows DRACH (1944).

Sex ratio variations were tested using the Chi square test $(\mathrm{P} \leq 0.05)$, considering a hypothetical 1:1 (males:females) relationship as reference. The influence of seasonal changes on the molt cycle was monthly analyzed, both on total population and also discriminating by sex and molt stage. Differences were tested taking as expected value that one of the month previous to the molt stage considered, and using the Chi square test $(\mathrm{P} \leq 0.05)$. Mean size differences among females, males, and juveniles were tested using the Students t-statistic $(\mathrm{P} \leq 0.05)$ (Sokal \& Rohlf, 1979).

\section{RESULTS}

A total of 1645 individuals ( 740 females, 539 males, and 366 juveniles) was analyzed. The relative abundance of prawns showed two maxima along the year, corresponding to February (202 individuals) and September (184 individuals). These peaks of abundance were not related to higher water temperatures (fig. 1), whereas the lowest value (4 individuals) was coincident with the lowest water temperature recorded $\left(4^{\circ} \mathrm{C}\right.$, in July).

Females predominated over males from January throughout July (45-75\%) and in September-October (46-59\%), gradually decreasing towards July. The number of males was significantly higher only in November. The sex ratio (males:females) was 1:1.4 during most of the year. Most sex ratios did not differ significantly from a 1:1 reference value; 
however, significant differences were found in February, March, and November (fig. 2).

The highest percentages of juveniles were found in December 1995 (65\%), August (56\%), and December 1996 (63\%). Juveniles were absent from the samples collected in July (in coincidence with the lowest catch of specimens), October and November (when the highest catch of ovigerous females was registered). Ovigerous females were present during the spring (October $48 \%$, November $30 \%$ ), then decreasing gradually towards the summer (January 18\%), to finally disappear between March and August (fig. 3).
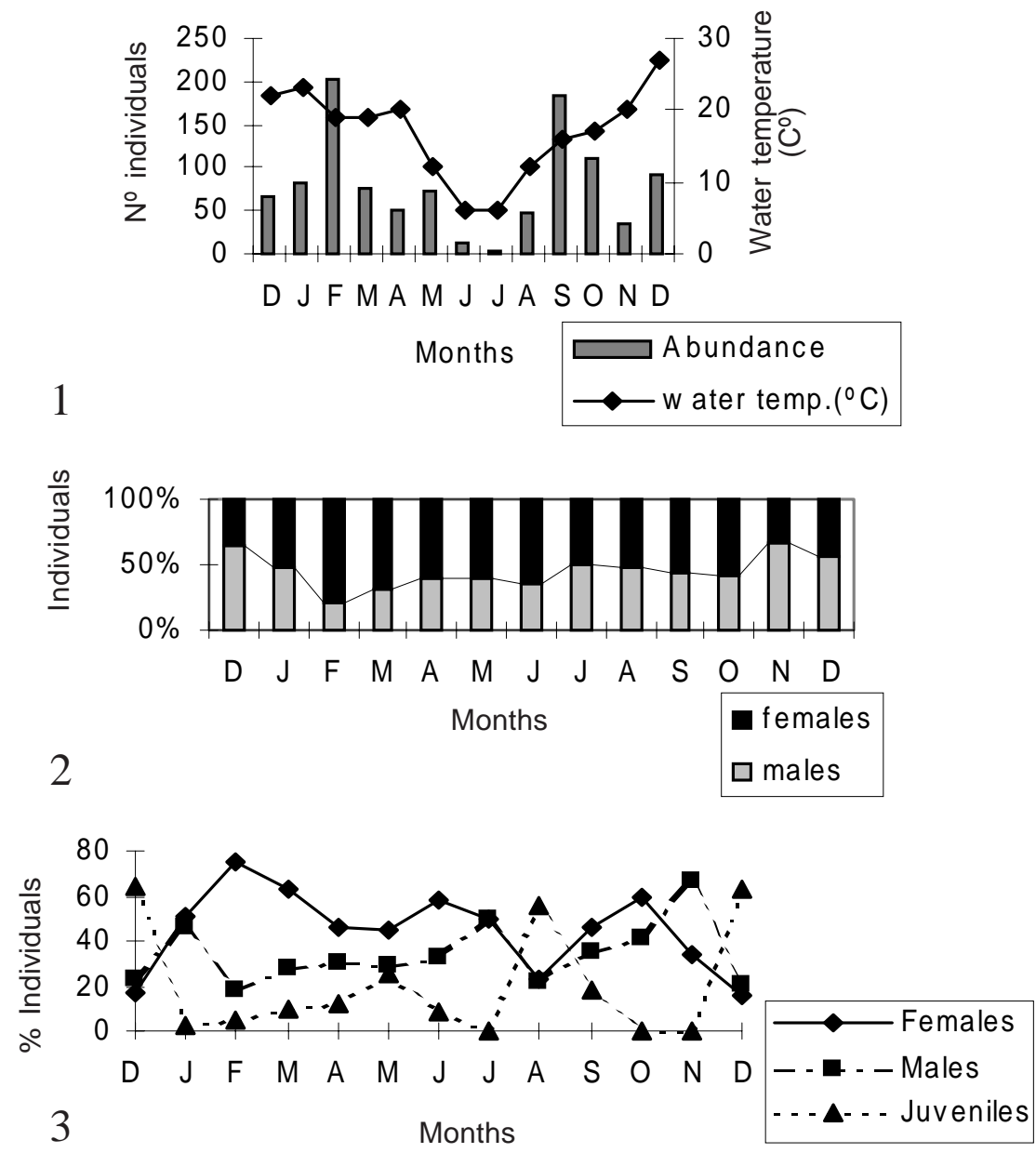

Figs. 1-3. Palaemonetes argentinus sampling between December 1995 and December 1996 from Los Padres Lagoon, Argentina: 1, abundance and water temperature variation; 2, annual variation in the sex ratio; 3 , monthly variation in the percentages of females, males and juveniles. 
The largest females were recorded in October $(26.7 \pm 1.65 \mathrm{~mm})$ and November $(27.3 \pm 2.07 \mathrm{~mm})$. During these months females were significantly larger than males, decreasing in size towards the beginning of the summer. The smallest females were recorded in January (17.25 $\pm 1.18 \mathrm{~mm}$ ) (fig. 4). During the breeding period (October and November), size of ovigerous females ranged from 20 to $31 \mathrm{~mm}$ (fig. 7). Male mean size was $19.9 \pm 2.52 \mathrm{~mm}$, showing its maximum value $(25.1 \pm 1.74 \mathrm{~mm})$ in November and its minimum ( $16.7 \pm 0.87 \mathrm{~mm}$ ) in August (fig. 5). Juveniles size ranged from $12.8 \pm 1.36$ to $14.5 \pm 0.61$ mm (fig. 6).
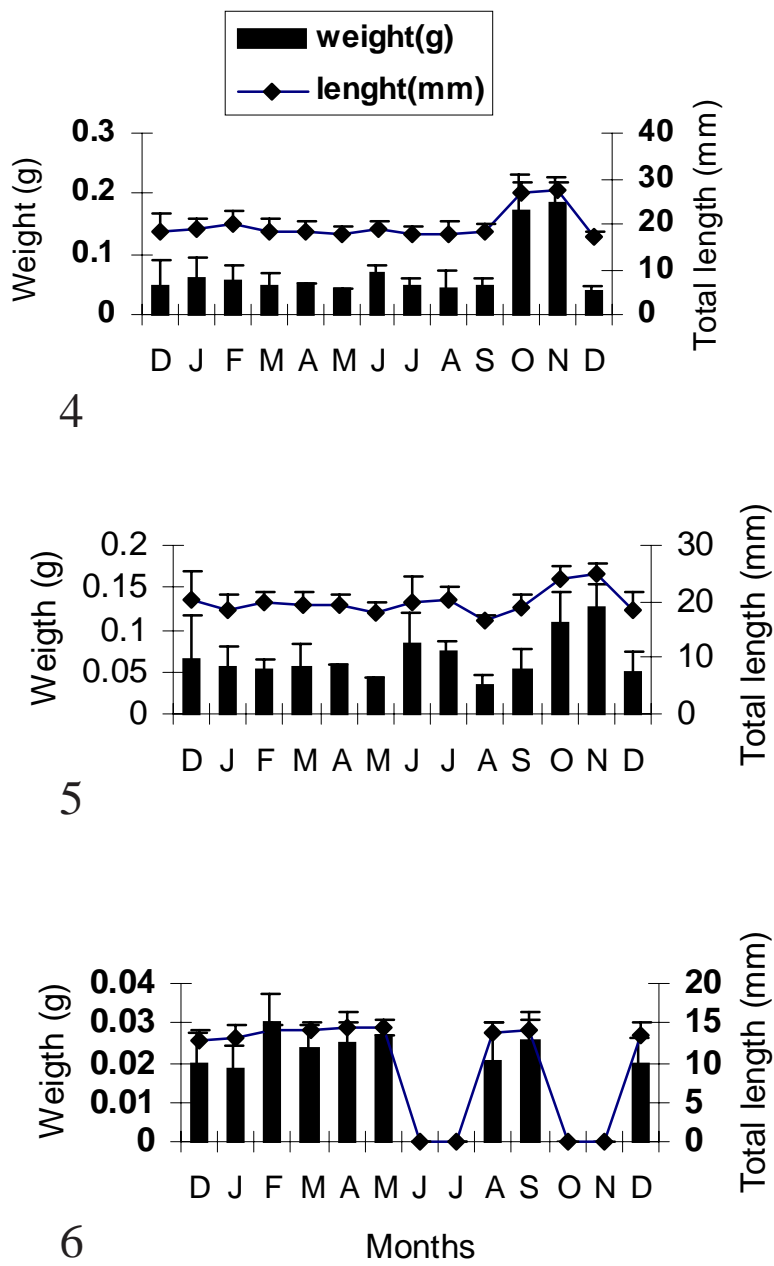

Figs. 4-6. Mean weight and size of Palaemonetes argentinus during the sampling period. 4, females; 5, males; 6, juveniles. Vertical lines represent the standard error of the mean. 
Female weight remained mostly constant throughout the year, with a mean value of $0.050 \pm 0.0080 \mathrm{~g}$, except between October and November, when it increased significantly over male weight $(0.171 \pm 0.0082 \mathrm{~g} v s .0 .184 \pm 0.0096 \mathrm{~g}$, respectively) (fig. 4). During these two months the weight of ovigerous females ranged from 0.054 to $0.220 \mathrm{~g}$ (fig. 8). The highest mean weights of males were attained in June-July $(0.084 \pm 0.038$ and $0.078 \pm 0.013 \mathrm{~g}$, respectively) and in October-November ( $0.101 \pm 0.035$ and $0.125 \pm 0.032 \mathrm{~g}$, respectively); during the rest of the year they are relatively uniform $(0.0517 \pm 0.009 \mathrm{~g})$ (fig. 5). Data analysis demonstrated that male mean weight was significantly higher than that of females during June and July, whereas lower in October and November. Juvenile mean weight remained constant $(0.023 \pm 0.003 \mathrm{~g})$ from December until June and from August until September (fig. 6).

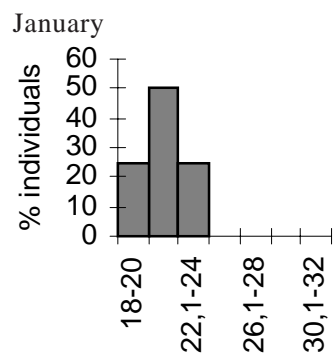

7

Lenght $(\mathrm{mm})$

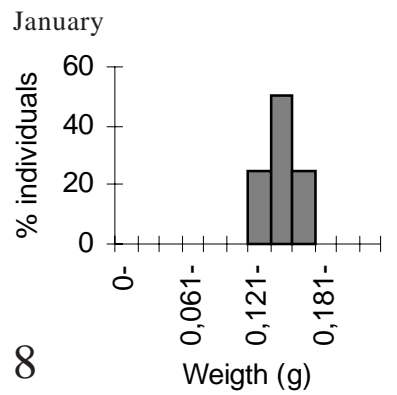

October

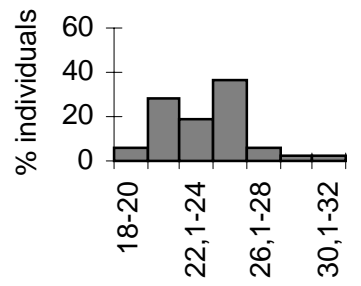

Lenght $(\mathrm{mm})$

October

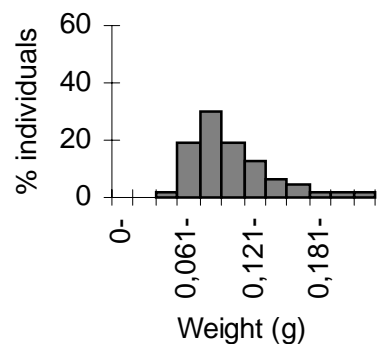

November

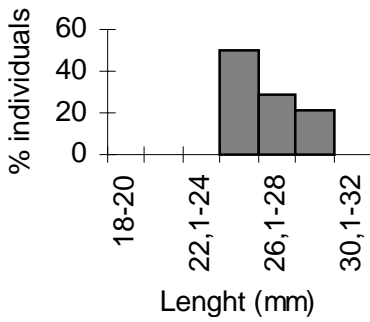

November

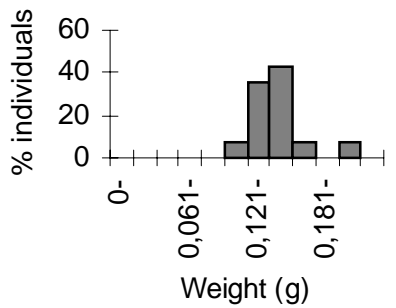

Figs. 7, 8. Variation in ovigerous females of Palaemonetes argentinus during January, October, and November 1996: 7, size; 8, weight.

Premolt prawns $\left(\mathrm{D}_{0}, \mathrm{D}_{1}\right.$, and $\left.\mathrm{D}_{2}\right)$ predominated throughout the whole year, with a mean percentage of $67 \%$. These stages experienced a significant decrease in June, October, and November. Postmolt stages (A and B) were the least represented, with a mean of $9 \%$ and $24 \%$ of the individuals was in intermolt (C) (fig. 9). The percentage of premolt individuals $\left(\mathrm{D}_{0}, \mathrm{D}_{1}\right.$, and $\left.\mathrm{D}_{2}\right)$ experienced an increase that tracked the rising of water temperatures (December 19\%, April 79\%); but from May until November it remained at a constant level (50-75\%). The number of postmolt individuals increased significantly 
at the end of the summer breeding season (May 9\%, June 25\%) and also at the end of the spring breeding season (November $17 \%$, December $15 \%$ ). The percentage of intermolt specimens (C) decreased significantly from December $\left(67 \%\right.$ at $\left.22^{\circ} \mathrm{C}\right)$ to April $(18 \%$ at $18^{\circ} \mathrm{C}$ ) and then remained at a constant level. The percentages corresponding to the spring months were statistically different. Ovigerous females arrest their molt cycle at the intermolt stage, and in coincidence with their appearance during the spring months (October and November, 29\%), the total percentage of intermolt stages in the population rose significantly (fig. 9).

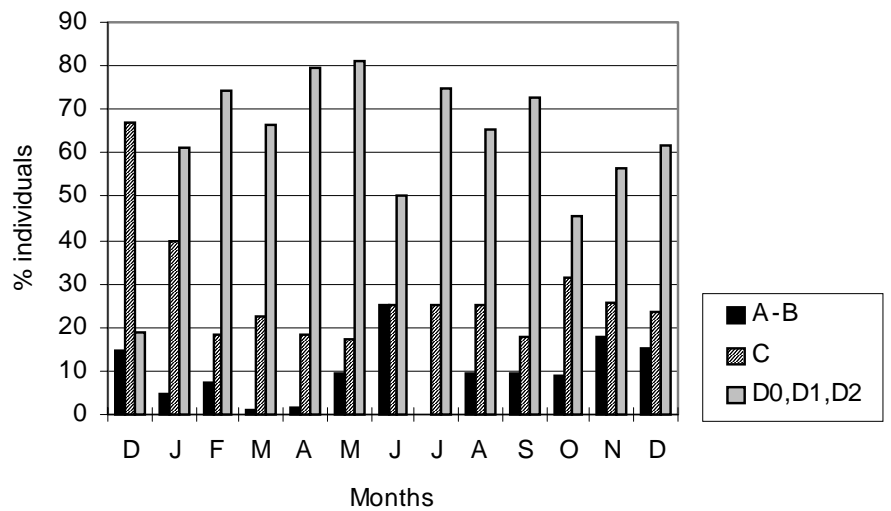

Fig. 9. Monthly variation in the molt stages of a natural population of Palaemonetes argentinus (A$\mathrm{B}$, postmolt; $\mathrm{C}$, intermolt; $\mathrm{D}_{0}, \mathrm{D}_{1}, \mathrm{D}_{2}$, premolt).

The percentage of premolt females $\left(\mathrm{D}_{0}, \mathrm{D}_{1}\right.$ and $\left.\mathrm{D}_{2}\right)$, ranged from 50 to $75 \%$ (in January-May and November-December, respectively) and was independent of water temperatures $\left(12-23^{\circ} \mathrm{C}\right)$. The significant decrease of premolt females recorded in June probably obeys to lower water temperatures, whereas the decrease observed in October may have been influenced by maturation. Postmolt stages (A and B) were the least represented throughout the year, except in June, when a significantly highest value $(50 \%)$ was recorded. The percentage of intermolt individuals (C) remained high in December-January $(60 \%, 40 \%)$ and in October-November $(45 \%, 30 \%)$, in coincidence with the highest number of ovigerous females, and also between July and August (50\%, $35 \%)$, when the lowest water temperatures $\left(6-12^{\circ} \mathrm{C}\right)$ were recorded (fig. 10).

Premolt stages of males $\left(\mathrm{D}_{0}, \mathrm{D}_{1}\right.$ and $\left.\mathrm{D}_{2}\right)$, were the best represented ones $(50-75 \%)$. Intermolt individuals $(C)$ remained at a constant level of $20 \%$ throughout most of the year, except in December 1995 and January, November, and December 1996, when they experienced a significant increase $(35 \%)$, in coincidence with the highest water temperatures $\left(20-23^{\circ} \mathrm{C}\right)$ recorded. Postmolt stages $(\mathrm{A}$ and $\mathrm{B})$ were the least represented ones (0-14\%) (fig. 11).

The percentage of premolt juveniles $\left(D_{0}, D_{1}\right.$ and $\left.D_{2}\right)$, remained high (75-90\%) from January until May, at water temperatures ranging from 12 to $23^{\circ} \mathrm{C}$. Intermolt prawns (C) represented 8 to $65 \%$ of the population throughout the year, and their percentage was independent of water temperature variations. Postmolt individuals (A and B) were the least represented stage, both among juveniles and adult individuals (0-15\%) (fig. 12). 

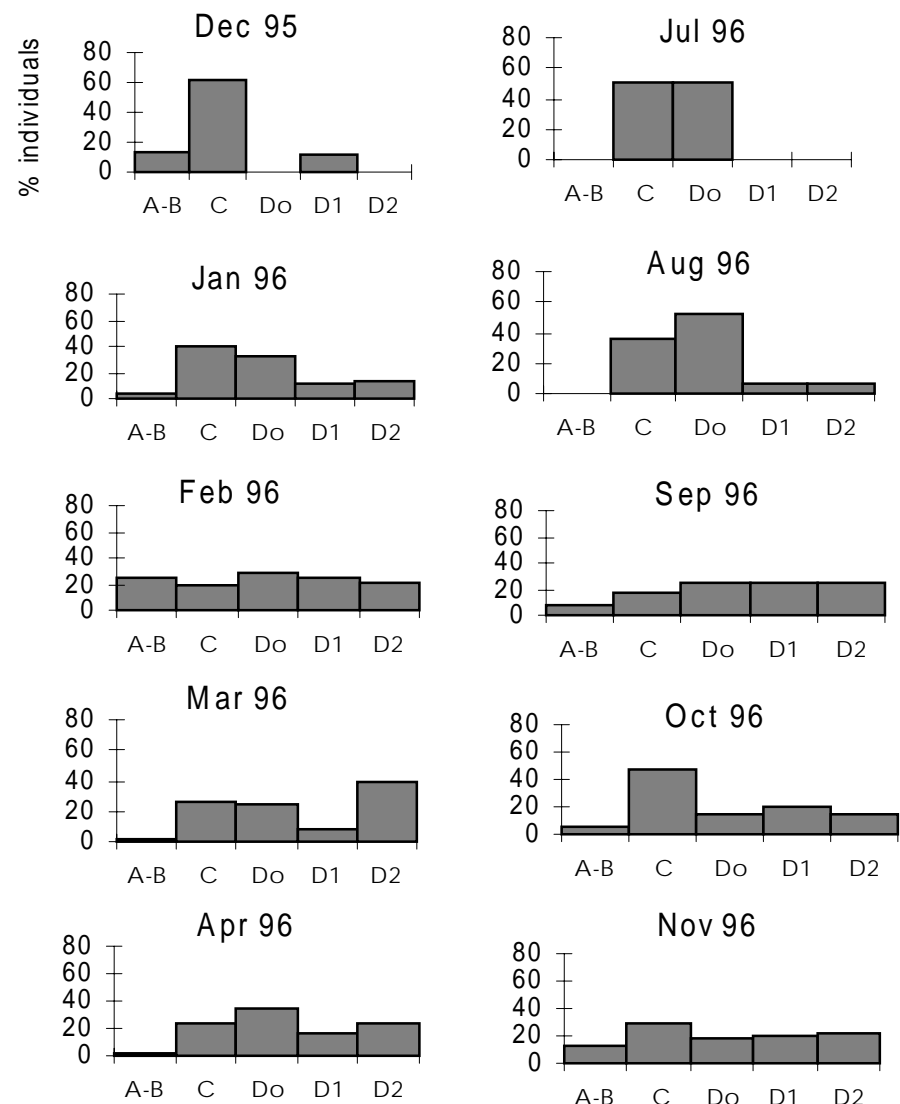

Nov 96
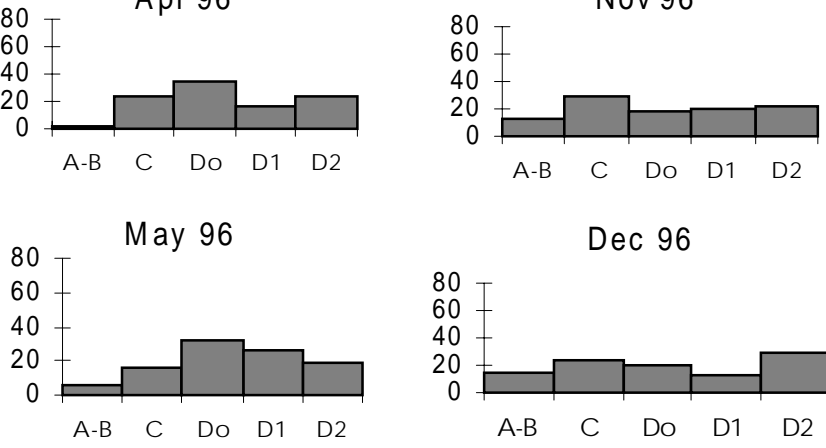

Dec 96
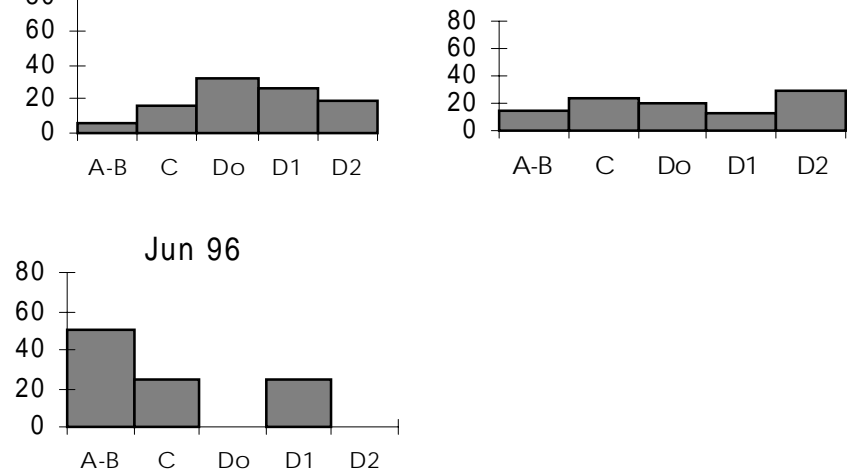

Fig. 10. Monthly variation in the molt stages of Palaemonetes argentinus females (A-B, postmolt; $\mathrm{C}$, intermolt; $\mathrm{D}_{0}, \mathrm{D}_{1}, \mathrm{D}_{2}$, premolt). 

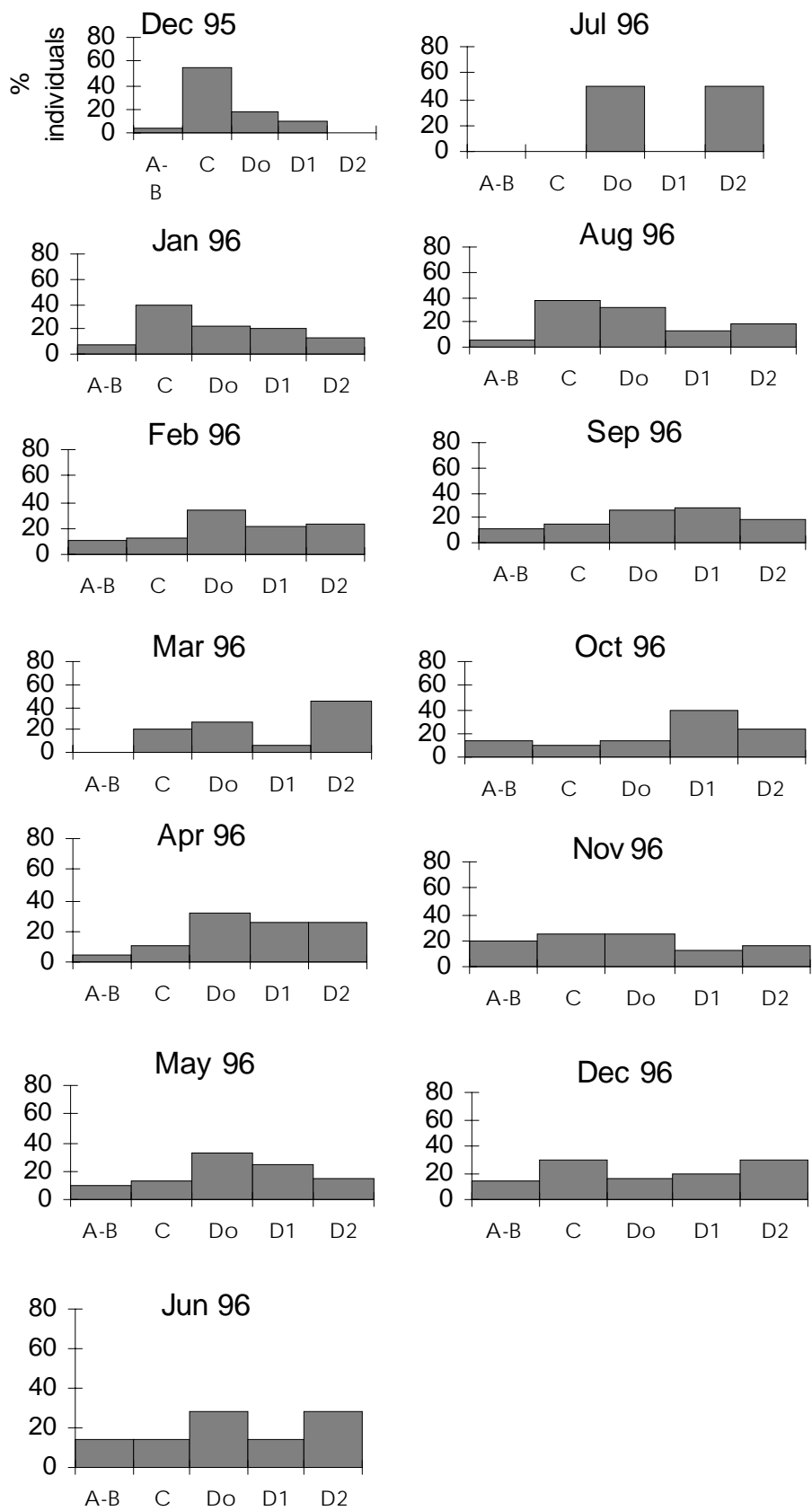

Fig. 11. Monthly variation in the molt stages of Palaemonetes argentinus males (A-B, postmolt; C, intermolt; $\mathrm{D}_{0}, \mathrm{D}_{1}, \mathrm{D}_{2}$, premolt). 

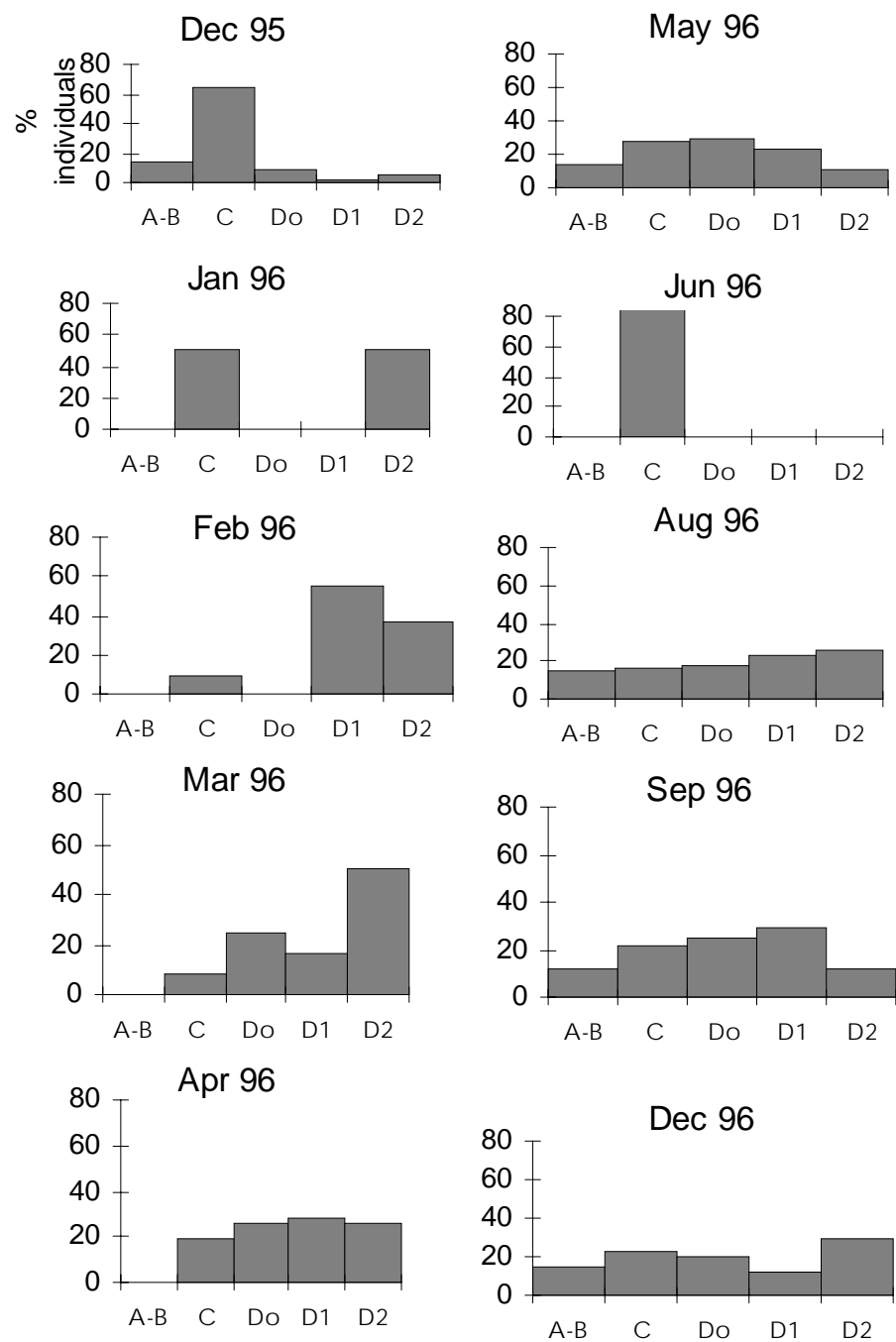

Fig. 12. Monthly variation in the molt stages of Palaemonetes argentinus juveniles (A-B, postmolt; $\mathrm{C}$, intermolt; $\mathrm{D}_{0}, \mathrm{D}_{1}, \mathrm{D}_{2}$, premolt).

\section{DISCUSSION}

Sex ratio analysis showed that females predominated over males during most of the year, in agreement with other authors (DonATTI, 1986; Rodriguez CAPÍTUlo \& FREYRE, 1989) however, since the species is associated to the bottom and to littoral vegetation, the fact that ovigerous females might be slower and therefore easier to catch than males should not be neglected (SANZ BraU, 1986; SouZa \& Fontoura, 1993). 
The temporal reduction in the number of individuals in the study area during the winter is not related to any particular size, but may be explained by seasonal migration of the population from the shore towards deeper zones in search of refuge from adverse environmental conditions, such as low temperatures and strong winds is coincident with the findings for the same species by DonATTI, 1986. These individuals come back at the littoral zone on spring when the climatic conditions changes and the water temperature increases, constituting the old generation individuals which survived after winter, and their size and weight indicate that they are at less one year old (RoDRIGUEz CAPítUlo \& FREYRE, 1989). For this reason the reduction of captures may be attributed to this kind of migration more than mortality.

The males are heavier than females in June and July, whereas lighter in October and November, when the highest number of ovigerous females was found. The differential behavior of weight in relation to sex is coincident with the findings by SouZA \& FONTOURA (1995) on Macrobrachium potiuna (Müller, 1880). Concerning size, and in agreement with the data published by MüLler \& ARAúso (1994), for this and other species of Palaemonidae (MüLLER et al., 1996), it was verified that males are proportionally smaller than females.

The breeding season of $P$. argentinus starts in September/October extending until January/February, in coincidence with the highest water temperatures. The maximum sexual activity occurs in the spring (October and November). This fact is evidenced by a great number of ovigerous females that reach their largest size. These results agree with those obtained by Goldstein \& Lauría DE Cidre (1974) and SpIVAK (1997) for the same species, as well as for other palaemonid species, such as Palaemon elegans Rathke, 1837 (SANZ, 1987) and M. potiuna (SouZA \& Fontoura, 1996).

Concerning juveniles, recorded marked fluctuations in their abundance periods, the highest percentages occurring in August/September and December, which may indicate the existence of two cohorts. The females of the first cohort, originated in the spring recruitment group, grow and mature rapidly due to favorable temperatures and to the availability of nutrients; this cohort accomplishes their first oviposition in the summer. After the winter, and already transformed into ovigerous females of a larger size, they accomplish their second oviposition at the beginning of the breeding season. The hatching of the second cohort occurs in December-January, representing the summer recruitment, which undergoes a slow growth and maturation process during the winter. Females corresponding to the smallest ovigerous size class of this season spawn for the first time in the spring. Individuals of both cohorts integrate the numerous group of spring ovigerous females. Former evidences indicate that few $P$. argentinus adult females reach the breeding season of their second year of life (RodRiguEZ CAPÍTUlo, 1992). In populations of the same species but from other regions of Argentina, the recruitment of juveniles is restricted to January-March (Schuldt \& Damborenea, 1989; SpivaK, 1997). RodRIGUEZ CAPítulo \& FREYRE (1989) have also described the existence of three cohorts corresponding to the reproductive periods of October, December, and January.

The relationship between reproduction and molt cycle was analyzed on the basis of data from a natural population. Ovigerous females arrest their intermolt cycle and restart it only after spawning. This cycle dynamics has already been described for several palaemonid species, such as Macrobrachium borellii (Nobili, 1896) and M. potiuna 
(Bond \& Buckup, 1982) and Palaemonetes varians (Leach, 1814) (Bouchon, 1991). In agreement with the observations on other decapods and some palaemonid species, such as Macrobrachium rosembergii (De Man, 1879) (RA'ANAN et al., 1991), we were able to determine that immature females of $P$. argentinus grow more than ovigerous females. This response may be explained taking into account that both ecdysis and reproduction demand the utilization of a great amount of energy, with the prevalence of maturation over molting. The allocation of energy towards reproduction inhibits tissue growth, thus reducing the pre-molt increment, extending the intermolt period (HARTNOLL, 1985; GUERAO et al., 1994), and resulting in gonad maturation at the expense of somatic growth (SAGI et al., 1997).

In this work, the absolute duration of each molting cycle stage was not determined, but the duration of each stage was estimated in relation to the proportion of individuals at each stage found in the samples, acording to DrACH (1944). Differences between the percentages of individuals in intermolt $(\mathrm{C})$ recorded during the months of temperatures maximum and minimum were not found, in agreement with the findings on Artemesia longinaris Bate, 1888 by PETRIELLA \& BRIDI (1992), who did not find significant differences in the intermolt duration between adults and juveniles, except for mature females. Our results contradict the observations by PASSANO (1960) and several authors, who working under controlled conditions of temperature and photoperiod, indicated that the molt cycle duration depends on individual size, and also that the intermolt period increases with age. Disagreement could be attributed to the annual variations of the water temperature in the lagoon $\left(4\right.$ to $\left.23^{\circ} \mathrm{C}\right)$, which would regulate the molting cycle, changing the effect caused by size.

Considering the criterion adopted for molt cycle categorization (DRACH, 1944), the higher number of premolt individuals indicates that this is the longest stage of a cycle that corresponds to the diecdysic type. This result coincides with the observations by Díaz et al. (1998) on P. argentinus, who determined, under laboratory conditions, that premolt stages comprise $60 \%$ of the cycle. Postmolt individuals represent the lowest percentage of the population year around, indicating that this is the shortest stage of a molt cycle of the diecdysic type. Such a proportion seems to be independent of water temperature and might be controlled by ovarian maturation.

In agreement with previous works (Drach, 1944; ScheER, 1960; Petriella \& BRIDI, 1992), it was determined that premolt duration presented only slight variations throughout the year, with a small shortening of the cycle in the spring and in the summer. During the rest of the year premolt was independent of water temperature. In other species, such as Palinurus argus (Latreille, 1804) (AIKEN, 1973) and A. longinaris (Petriella \& BRIDI, 1992), low water temperatures (below a certain value) inhibit the molt cycle. Conversely, this factor does not seem to affect postmolt in P. argentinus. An increase in the percentage of individuals belonging to this stage at the end of both breeding seasons may coincide with the restarting of the cycle by those females that have already spawned. Intermolt duration increases significantly in those months when the highest number of ovigerous females was found. This result is in agreement with observations carried out on mature females that arrest their cycle in this stage to restart it after oviposition. The study indicates that, at least in females, water temperature does not modify molt frequency, but this aspect of the cycle is clearly influenced by ovarian maturation. 


\section{REFERENCES}

Adiyodi, R. G. 1985. Reproduction and its control. In: Bliss, D. E. \& Mantel, L. H. eds. The biology of Crustacea. Orlando, Academic. v.9, p.147-215.

Adiyodi, R. G. \& Adiyodi, K. G. 1970. Endocrine control on reproduction in decapod crustacea. Biol. Rev., Cambridge, 45:121-165.

Airen, D. E. 1969. Photoperiod, endocrinology and crustacean molt cycle. Science, Washington, 164:149-155.

1973. Proecdysis, setal development and molt prediction in American lobster (Homarus americanus). J. Fish. Res. Bb Can., Ontario, 30(9):1337-1344.

1980. Molting and growth. In: CoBB, J. S. \& Phillips, B. F. eds. The biology and management of lobsters, physiology and behavior. New York, Academic. v.1, p.91-147.

BLIss, D. E. 1966. Physiological process and neurosecretion as related to ecdysis and reproduction. Relation between reproduction and growth in Decapod Crustaceans. Am. Zool., Thousand, 6:231-233.

Bond, G. \& Buckup, L. 1982. O ciclo reprodutor de Macrobrachium borellii (Nobili, 1896) e Macrobrachium potiuna (Müller, 1880) (Crustacea, Decapoda, Palaemonidae) e suas relações com a temperatura. Revta bras. Biol., Rio de Janeiro, 42(3):473-483.

Bouchon, D. 1991. Biological clock in seasonal reproductive cycle in the ditch shrimp Palaemonetes varians Leach. I. Photoperiodic time measurement. J. Exp. Mar. Biol. Ecol., Amsterdam, 146: $1-12$.

Chang, E. S. 1993. Comparative endocrinology of molting and reproduction: insects and crustaceans. A. Rev. Ent., Palo Alto, 38:161-180.

Díaz, A. C.; Petriella, A. M. \& Sousa, L. G. 1998. Setogenesis and growth of the freshwater prawn Palaemonetes argentinus (Decapoda, Caridea, Palaemonidae). Iheringia, Sér. Zool., Porto Alegre, (85):59-65.

DonAtTi, O. D. 1986. Algunos aspectos bioecológicos del camarón Palaemonetes argentinus (Nobili, 1901) en el embalse San Roque, Córdoba, (Argentina). Revta Hydrobiol. trop., Paris, 19(1):4560 .

Drach, P. 1944. Étude préliminaire sur le cycle dintermue et son conditionnement hormonal chez Leander serratus (Pennant). Bull. Biol. Fr. Bel., Paris, 78:40-62.

1955. Systéme endocrinien pedonculaire, durée d'intermue et vitellogénese chez Leander serratus (Pennant), Crustacé, Decapode. C. R. Soc. Biol., Paris, 149:2079-2083.

Drach, P. \& TchernigovtzefF, C. 1967. Sur le méthode de la détermination des stades d'intermue et son application générale aux crustacés. Vie Milieu, Ser. A, Paris, 18:595-610.

Goldstein, B. \& Lauría de Cidre, L. 1974. Ciclo de maduracion sexual y observaciones preliminares sobre el desove del camarón dulceacuícola Palaemonetes argentinus (Nobili, 1901) (Crustacea, Caridea, Palaemonidae). I. Hembra. Physis, Ser. B, Buenos Aires, 33(87):165-176.

Guerao, G.; Pérez-Baquera, J. \& Rivera, C. 1994. Growth and reproductive biology of Palaemon xiphias Risso, 1816 (Decapoda: Caridea: Palaemonidae). J. Crustacean Biology, Kansas, 14(2):280-288.

Hartnoll, R. G. 1982. Growth. In: Bliss, D. E. ed. The biology of Crustacea. New York, Academic. v.2, p.111-196.

1985. Growth, sexual maturity and reproductive output. In: WennER, A. M. ed. Crustacean Issues. Factors in adult growth. Rotterdam, Balkema, v.3, p.101-128.

Lipcius, R. N. 1985. Size-dependent reproduction and molting in spiny lobsters and other long-lived decapods. In: Wenner, A. M. ed. Crustacean Issues. Factors in adult growth. Rotterdam, Balkema, v.3, p.129-148.

Menu Marque, S. A. 1973. Desarrollo larval de Palaemonetes argentinus (Nobili, 1901) en el laboratorio (Crustacea, Caridea, Palaemonidae). Physis, Buenos Aires, 32(85):149-169.

Müller, Y. M. R. \& Araúso, J. 1994. Dados biológicos de Palaemonetes argentinus (Decapoda, Palaemonidae) coletados no canal do rio Ratones, Florianópolis, SC. Revta bras. Biol., Rio de Janeiro, 54(3):443-449.

Müller, Y. M. R.; NAzARi, E. M. et al. 1996. Aspectos da reprodução de Palaemon pandaliformis (Stimpson) (Decapoda, Palaemonidae) no Manguezal de Ratones, Florianópolis, Santa Catarina. 
Revta bras. Zool., Curitiba, 13(3):633-642.

Passano, M. L. 1960. Molting and its control. In: Waterman, T. H. ed. The physiology of Crustacea, New York, Academic. p.473-536.

Petriella, A. M. \& BRIDI, R. J. 1992. Variaciones estacionales del ciclo de muda y la maduración ovárica del camarón (Artemesia longinaris). Frente Marítimo, Mar del Plata, 11A:85-92.

RA'ANAN, A.; SAGI, A. et al. 1991. Growth, size rank, and maturation of the freshwater prawn, Macrobrachium rosembergii: analysis of marked prawns in an experimental population. Biol. Bull., Woods Hole, 181:379-386.

Rodrigues Capítulo, A. 1992. Tablas de vida ecológicas de supervivencia y fecundidad de Palaemonetes (P.) argentinus (Crustacea, Palaemonidae). Physis, Ser. B, Buenos Aires, 47(113):41-50.

Rodrigues Capítulo, A. \& Freyre, L. R. 1989. Demografía de Palaemonetes (Palaemonetes) argentinus Nobili (Decapoda, Natantia). 1. Crecimiento. Limnobios, La Plata, 2(10):744-756.

SAGi, A.; Shoukrun, R. et al. 1997. Reproduction and molt of previously spawned and first-time spawning red-clow crayfish Cherax quadricarinatus females following eyestalk ablation during the winter reproductive-arrest period. Aquaculture, Amsterdan, 156:101-111.

SAnZ, A. 1987. Biología de Palaemon elegans Rathke, 1837 (Natantia: Palaemonidae) en las costas del Mediterráneo Occidental. Inv. Pesq., Burjasot, 51(Supl.1):177-187.

Sanz Brau, A. 1986. Biología del Camarón de agua dulce Palaemonetes zariquieyi Sollaud, 1939 (Crustacea: Decapoda: Palaemonidae). Limnética, Madrid, 2:293-304.

Scheer, B. T. 1960. Aspects of intermolt cycle in natantians. Comp. Biochem. Physiol., Oxford, 1:3-18.

Schuldt, M. \& Damborenea, M. C. 1989. Infección de Palaemonetes argentinus (Crustacea, Palaemonidae) con Probopyrus cf. oviformis (Crustacea, Bopyridae) en el canal de Villa Elisa (selva marginal de Punta Lara, provincia de Buenos Aires, Argentina). 1, Estructura poblacional del consorcio, interacción y fluctuación. Biota, Osorno, 5:21-53.

SoKal, R. \& Rohlf, J. 1979. Biometría. Madrid, H. Blume. 832 p.

Sousa, L. G. \& Petriella, A. 2000. Histology of the hepatopancreas of the fresh water prawn Palaemonetes argentinus ( Crustacea, Caridea). Biocell, Mendoza, 24(3):189-195.

2001. Changes in the hepatopancreas histology of Palaemonetes argentinus (Crustacea, Caridea) during molt. Biocell, Mendoza, 25(3):275-281.

Sousa, L.; Petriella, A. \& Díaz, A. C. 1997. Modificaciones del tegumento de Palaemonetes argentinus (Crustacea, Decapoda, Caridea) durante el ciclo de muda. Iheringia, Sér. Zool., Porto Alegre, (83):3-12.

SouZA, G. D. \& Fontoura, N. F. 1993. Estrutura populacional e fecundidade de Pachygrapsus gracilis (Saussure, 1858) no molhe do rio Tramandai, Rio Grande do Sul, Brasil (Crustacea, Decapoda, Grapsidae). Comun. Mus. Cienc. PUCRS, Porto Alegre, 52:29-37.

1995. Crescimento de Machobrachium potiuna no arroio Sapucaia, Município de Gravataí, Rio Grande do Sul (Crustacea, Decapoda, Palaemonidae). Revta bras. Biol., Rio de Janeiro, 55(1):51-63.

1996. Reprodução, longevidade e razão sexual de Machobrachium potiuna (Müller, 1880) (Crustacea, Decapoda, Palaemonidae) no arroio Sapucaia, município de Gravataí, Rio Grande do Sul. Nauplius, Rio Grande, 4:49-60.

SpIVAK, E. D. 1997. Life history of a brackish-water population of Palaemonetes argentinus (Decapoda: Caridea) in Argentina. Annls Limnol., Toulouse, 33(3):1-12.

Recebido em 23.09.2002; aceito em 10.07.2003. 